\title{
FAKTOR YANG PENGARUHI PEMILIHAN KARIR SEBAGAI AKUNTAN PUBLIK BAGI MAHASISWA PTS WASTA DENGAN PENDEKATAN REASONED ACTION MODEL
}

\author{
Hendro Lukman \& Carolina Juniati \\ Fakultas Ekonomi Universitas Tarumanagara \\ Email: hendrolukman@gmail.com
}

\begin{abstract}
The objective of this study was to analyze the influence of intrinsic value, gender, parental influence, perception of student and labor market considerations for choosing a career as a public accountant. This research is done based as a phenomenon that occurs today, which is the number of people who holds accountant in Indonesia but at least who pursue as a public accountant. Theory of Reasoned Action Model (TRA Model), which suggests that the attitude (intrinsic value) and subjective norm (parental influence) became the basis for the behavior of the individual as the premises of the study. The subjects of this study were students majoring in accounting at the private university in Jakarta that many graduates working in public accounting firms. The sample in this study amounted to 196 respondents through spreading a questionnaire to students diretly, and processed using SPSS Version 21. The results are intrinsic values, perceptions of student and parental influence has a significant influence on the tendency of students to work as a public accountant, while gender and labor market considerations does not have a significant effect. According to The TRA Model, this research result is consistent with TRA model. Therefore, the role of associations of public accountants in the case of Indonesian Institute of Certified Public Accountants (IAPI) and the universities must play an active role creates a clear prospect information and public accounting profession.
\end{abstract}

Keywords: intrinsic factor, gender, parental influence, student perceptions, job market factor, CPA career, TRA Model

\begin{abstract}
Abstrak: Tujuan dari penelitian ini adalah untuk mengalisis pengaruh nilai instrinsik, gender,pengaruh orang tuan, persepsi mahasiswa dan pertimbangan pasar untuk memilih karir sebagai akuntan publik. Riset ini dilaksanakan berdasarkan fenomena yang terjadi saat ini di mana jumlah pemegang gelar akuntan yang banyak namun yang berprofesi sebagai akuntan publik sedikit sekali. Teori Reasoned Action Model (TRA Model) yang menilai prilaku (instrinsik) dan norma subyektif (pengaruh orang tua) menjadi dasar dari prilaku individu sebagai dasar penelitian ini. Subyek dari penelitian ini adalah mahasiswa akuntansi di perguruan tinggi swasta di Jakarta yang kebanyakan mereka bekerja di kantor akuntan publik setelah mereka lulus. Jumlah sampel 196 responden yang diperoleh dengan menyebarkan kusioner secara langsung dan diproses menggunakan SPSS versi 21. Hasil penelitian ini menunjukkan nilai instrinsik, persepsi mahasiswa dan pengaruh orang tuan mempunyai signifikan terhadap kecenderungan mahasiswa bekerja sebagai akuntan publik, sementara gender dan pertimbangan pasar kerja tidak mempunyai efek signifikan. Berdasarkan TRA Model, hasil riset ini konsisten dengan TRA Model. Dengan demikian, peranan Institut Akuntan Publik Indonesia (IAPI) dan pergutuan tinggi harus berperan aktif menciptakan informasi yang jelas mengenai prospek profesi sebagai akuntan publik.
\end{abstract}


Kata kunci: intrinsic factor, gender, parental influence, student perceptions, job market factor, CPA career, TRA Model

\section{PENDAHULUAN}

Perencanaan karir merupakan suatu hal yang sangat penting untuk mencapai kesuksesan dalam karir (Berry dalam Harris dan Djamhuri, 2001). Hal inilah yang harus menjadi pertimbangan lebih bagi para mahasiswa yang terutama dari jurusan akuntansi dikarenakan karir dalam bidang akuntansi yang cukup luas dan beragam, salah satunya adalah akuntan publik. Merencanakan karir dari awal dapat memacu seseorang merencanakan pendidikan, keahlian dan ketrampilan yang mendukung pencapaian karir yang akan dituju.

Jumlah akuntan publik di Indonesia, secara kuantitas masih jauh dari kebutuhan jasa ini bagi dunia usaha, hanya sekitar 1019 akuntan yang berpraktik sebagai publik pada tahun 2013 menurut Institut Akuntan Publik Indoneisa (IAPI), sedangkan sarjana yang memegang gelas akuntan melebihi jumlah 50.000. Di lain sisi, akhir tahun 2015, Masyarakat Ekonomi Asean akan diberlakukan, di mana pasar bebas ASEAN ini bukan hanya berlaku dalam bidang perdagangan, melainkan juga bidang jasa, termasuk jasa akuntan. Jasa akuntansi yang masuk ke pasar bebas ASEAN termasuk untuk profesi akuntan sebagai akuntansi manajemen dan akuntansi publik. Untuk akuntan publik masih dibatasi untuk pekerjaan audit yang tidak termasuk untuk "menandatangani” laporan audit.

Sebagai perbandingan, jumlah akuntan yang berprofesi sebagai akuntan publik tahun 2012, menurut data dari Pusat Pembinaan Akuntan dan Jasa Penilai (PPAJP) Kementerian Keuangan (2013), di Malaysia tercatat sekitar 2.500 orang, Thailand sekitar 6.000 orang dan Filipina berjumlah 4.941 orang (http://www.kemlu.go.id), dan Singapore lebih dari 28.000 (www.isca.org.sg). Fenomena tersebut menjadi hal yang menarik untuk diteliti dengan pendekatan psikologis mengenai faktor yang menyebabkan mahasiswa tidak ingin meniti karirnya di profesi akuntan publik, terutama bagi mahasiswa di perguruan tinggi swasta yang umumnya mahasiswa ini ingin mempunyai usaha sendiri dibanding bekerja dengan orang lain.

Berdasarkan uraian pada latar belakang di atas, maka yang menjadi pokok permasalahan adalah apakah nilai intrinsik, gender, parental influence, persepsi mahasiswa, dan pertimbangan pasar kerja berpengaruh terhadap pemilihan karir sebagai akuntan publik bagi mahasiswa akuntansi. Subyek dalam penelitian ini adalah mahasiswa jurusan akuntansi yang minimal telah lulus mengambil mata kuliah audit atau semester terakhir pada universitas swasta di Jakarta yang mana para lulusannya sebagian besar bekerja di kantor akuntan sebagai tempat kerja pertama. Diharapkan sampel ini mewakili untuk masukan bagi perguruan tinggi dan pemerintah melalui IAPI untuk mengetahui faktor yang mempengaruhi pemilihan profesi sebagai akuntan publik dan usaha untuk meningkatkannya.

\section{KAJIAN TEORI}

The Theory of Reasoned Action Model (TRA model). Menurut Law (2010) dalam jurnalnya menyatakan bahwa "The TRA model finds its origins in field of social 
psychology" (TRA model menjelaskan suatu asal-usul di bidang psikologi sosial). Model ini dikembangkan oleh Fishbein dan Ajzen dalam Law (2010) ini yang a person's behavior is determined by its behavioral intention to perform it. This intention is itself determined by the person's attitudes and their subjective norms towards the behavior." Attitude dijelaskan sebagai (Law, 2010) sebagai sikap terhadap perilaku yang dituangkan dalam perasaan positif atau negatif secara individu dalam bertindak. Hal ini ditentukan melalui penilaian dari keyakinan seseorang mengenai konsekuensi yang timbul dari perilaku dan evaluasi keinginan konsekuensi. Secara formal, sikap keseluruhan dapat dinilai sebagai akumulasi dari penilaian keinginan konsekuensi tertentu dari individu untuk semua konsekuensi yang diharapkan dari perilakunya (Law, 2010). Sedangkan Subjective norms adalah didefinisikan sebagai persepsi individu dari orang-orang penting untuk individu berpikir untuk melakukan pemikiran msereka. Kontribusi pendapat setiap rujukan yang diberikan dipertimbangkan dengan motivasi bahwa seseorang harus memenuhi keinginan rujukan itu. Oleh karena itu, secara keseluruhan norma subjektif dapat dinyatakan sebagai jumlah atau akumulasi dari penilaian motivasi persepsi tertentu bagi individu untuk semua acuan yang relevan (Law, 2010).

Hubungan Attitudes dan Subjects Norms dalam keingin berprilaku seseorang dapat digambarkan seperti dibawah ini.

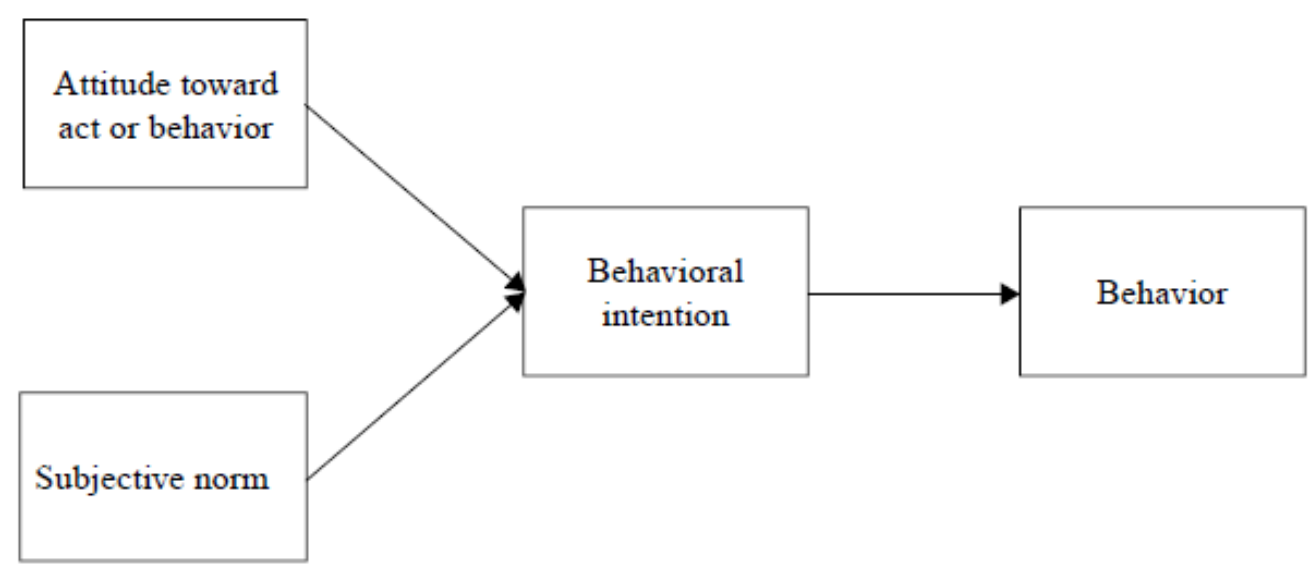

Gambar 1 : The Theory of Reasoned Action Model

Sumber : Fishbein dan Ajzen dalam Law (2010)

Lebih lanjut Law (2010) menjelaskan bahwa TRA digunakan sebagai model yang berhubngan antara attitudes dan pemilihan karis seseorang. Model ini memberikan suatu social psychological framework yang berguna menjelaskan jenis-jenis prilaku (Ajzen and Fishbein, 1980; Sheppard et al., 1988; Sable et al., 2006 dalam Law 2010), dan telah direkomendasikan sebagai suatu yang kerangka yang berguna untuk eksaminasi variabelvariabel yang mempengaruhi pemilihan karir (Cohen and Hanno, 1993 dalam Law 2010). TRA yang mencirikan perilaku manusia sebagai sesuatu yang “disengaja” (intentional) dan rasional (rational). Dengan demikian, TRA dapat memprediksi bahwa niat siswa untuk mengejar karir harus sangat terkait dengan attitude dan Subjectives Norms terhadap karir itu. Temuan dukungan empiris untuk model TRA dalam hal pilihan karir akuntansi memiliki implikasi penting bagi para pembuat kebijakan. Jika ini adalah keputusan yang rasional berdasarkan keyakinan tentang profesi, itu berarti bahwa kita dapat menarik bagi 
alasan siswa, daripada emosi mereka, ketika mencoba untuk menarik kandidat berkualitas tinggi dengan akuntansi (Law, 2010).

Teori Hirarki Kebutuhan. Teori Hirarki Kebutuhan dikembangkan oleh Abraham Maslow. Maslow (1987) menjelaskan bahwa setiap orang terdapat sebuah hirarki dari lima kebutuhan. Kelima kebutuhan menurut Maslow yang diterjemahkan bebas sebagai berikut: (1) Physiological needs. Kebutuhan seseorang akan makanan, minuman, tempat berteduh, seks, dan kebutuhan fisik lainnya; (2) Safety needs. Kebutuhan akan keamanan dan perlindungan dari kejahatan fisik dan emosional, serta menjamin bahwa kebutuhan fisik akan terus dipenuhi; (3) Love and belonging. Kebutuhan akan kasih saying, rasa memiliki, penerimaan dan persahabatan; (4) Esteem. Kebutuhan akan faktor penghargaan internal seperti harga diri, otonomi, dan prestasi serta faktor penghargaan eksternal seperti status, pengakuan dan perhatian; (5) Self-actualization. Kebutuhan akan pertumbuhan, pencapaian potensi seseorang dan pemenuhan diri serta dorongan untuk menjadi apapun yang diinginkan. Dari kelima kebutuhan di atas, esteem dan self-actualization diteliti melalui variabel persepsi mahasiswa $\left(\mathrm{X}_{4}\right)$ serta safety need diteliti melalui pertimbangan pasar kerja $\left(\mathrm{X}_{5}\right)$.

Pengembangan Hipotesis. Atas dasar The Theory of Reasoned Action Model (TRA model) dan Teori Hirarki Kebutuhan, dikembangkan hipotesis yang digunakan dalam penelitian ini. Pemilihan Karir sebagai Akuntan Publik sebagai variabel dependen yang merupakan niat mahasiswa Jurusan Akuntansi untuk memilih karir sebagai akuntan publik. Menurut Peraturan Menteri Keuangan Nomor: 17/PMK.01/2008 tentang Jasa Akuntan Publik menjelaskan bahwa "Akuntan Publik adalah akuntan yang telah memperoleh izin dari Menteri untuk memberikan jasa sebagaimana diatur dalam Peraturan Menteri Keuangan” (Agoes dan Ardana, 2009). Mulyadi (1998:3) menjelaskan bahwa timbulnya kebutuhan atas jasa akuntan publik dikeranakan pihak luar perusahaan memerlukan jasa pihak ketiga untuk menilai keandalan pertanggungjawaban keuangan yang disajikan oleh manajemen. Harris dan Djamhuri (2001) melihat dari dimensi yang berbeda, profesi akuntan adalah pekerjaan yang tidak hanya berhubungan dengan pemenuhan kebutuhan hidup semata, tetapi juga memerlukan standar-standar kualitas, kode etik profesi sehingga integritas profesi akuntan senantiasa terjaga, dan akuntan semestinya senantiasa menjaga hubungan baik dengan lingkungan masyarakat disekitarnya.

Variabel dependen diukur dengan butir pertanyaan di kuesioner.

a. Nilai Intrinsik. Nilai intrinsik adalah nilai yang dikejar demi kepentingan diri sendiri. Yang termasuk dalam nilai ini adalah keinginan manusia dalam memenuhi kesehatan tubuh dan jiwanya, ilmu pengetahuan, kedamaian batin, persahabatan, dan kebutuhan religius (Mangunhardjana. 1997: 15). Felton, Burh dan Northey (1994) menjelaskan bahwa faktor-faktor interisik diasosiasikan dengan kepuasan yang dicapai dari melakukan pekerjaan sebagai kesempatan untuk kreatif, otomatis, mengembangkan intelektual, dan lainnya. Lain halnya dengan Reckers and Bates dalam Law (2010) yang melihat dengan dimensi yang berbeda mengatakan bahwa sebuah karakterisasi umum bahwa profesional akuntan sebagai yang membosankan dan secara metodis. Sedangkan Tan dan Laswad (2006) cenderung memiliki pendapat yang sama dengan Felton, Burh dan Northey. Oleh karenanya Law (2010) mengungkapkan bahwa intrinsic factor 
sebagai salah satu komponen dari TRA model yang mencerminkan attitude atau belief dalam TRA model.

Dalam konteks penelitian ini, nilai intrinsik dimaksud adalah suatu nilai yang berhubungan dengan kepuasaan yang diperoleh dari melakukan suatu pekerjaan, yakni sebagai akuntan publik.

$\mathrm{H}_{1}$ : Nilai intristik mempunyai pengaruh terhadap pemilihan karir sebagai akuntan publik.

b. Gender. Gender adalah ciri-ciri yang membedakan pria dan wanita. Secara ekspilisit dibedakan secara fisik atau faktor eksternal. Namun, pembedaan secara implisit atau internal seperti sifat, emosi, ketelitian, perasaan, dan faktor implisit lainnya juga memberda yang dimiliki seorang pria dan wanita. Dengan kondisi fisik dan faktor internal, gender akan mempengaruhi jenis pekerjaan yang menjadi tujuannya. Dengan kondisi fisik dan faktor internal, gender akan mempengaruhi jenis pekerjaan yang menjadi tujuannya. Akuntansi sebagai suatu profesional menurut pandangan yang secara tradisional didominasi oleh kaum pria dengan sedikit kaum wanita yang masuk kualifikasi dalam badan profesional (Jackling dan Calero, 2006). Hal ini berbeda dengan yang diungkapkan oleh Law (2010) yang meneliti di Hong Kong menyebutkan bahwa kebanyakan wanita yang memasuki profesi akuntan publik. Dari Financial System Council dalam Sugahara, Hiramatsu dan Boland (2009) berpendapat bahwa profesi mempertimbangkan bahwa dengan mengembangkan keseimbangan gender dimasa yang akan datang akan terjadi

Variabel ini merupakan pengaruh terhadap pemilihan karir sebagai akuntan pubik. $\mathrm{H}_{2}$ : Gender mempunyai pengaruh terhadap pemilihan karir sebagai akuntan publik.

c. Parental Influence. Karir anak dapat dipengaruhi orang tua. Orang tua adalah teladan dan contoh yang dikagumi oleh seorang anak dari kecil, termasuk kesuksesan orang dimasa anak sudah mengenal dunia dan hendak memilih karir demi masa depannya. Selain itu, ketidakberdayaan anak dari kecil selalu diarahkan oleh orang tua menurut kehendak orang tua juga akan mempengaruhi karir mereka. Law (2010) menyatakan bahwa parental influence adalah salah satu komponen dari TRA model yang mencerminkan subjective norms Dengan demikian, Parental Influence adalah pengaruh pendapat orang tua terhadap pemilihan karir sebagai akuntan publik.

$\mathrm{H}_{3}$ : Parental Influence mempunyai pengaruh terhadap pemilihan karir sebagai akuntan publik.

d. Persepsi Mahasiswa. Persepsi mahasiswa merupakan proses penafsiran mahasiswa setelah mempelajari/ mengalami banyak hal dalam proses pembelajaran dan melihat kesuksesan orang lain dalam pekerjaan mereka. Robbins (2008) berpendapat bahwa persepsi adalah proses di mana individu mengartikan lingkungan sekitar dengan menyusun dan menginterprestasikan impresi sensoris. Perilaku seseorang sering kali didasarkan pada persepsi individu tentang suatu kenyataan. Persepsi seseorang terhadap profesi akuntan publik dipengaruhi oleh citra yang melekat pada profesi tersebut, yang merupakan bagian tidak terpisahkan dari lingkungan masyarakat. Masyarakat pada umumnya mengenal suatu profesi tergantung dari usaha yang dilakukan dan jasa apa yang diberikan oleh profesi tersebut kepada masyarakat sesuai dengan keahlian yang mereka miliki (Chua et at, dalam Harris dan Djamhuri, 2001). Persepsi Mahasiswa merupakaan variable terhadap pilihan karir sebagai profesi akuntan publik. 
$\mathrm{H}_{4}$ : Persepsi Mahasiswa mempunyai pengaruh terhadap pemilihan karir sebagai akuntan

e. Pertimbangan Pasar Kerja. Pertimbangan masa depan suatu karir yang mudah diakses atau tersedia yang mana akan ditekuni dan dijalankan pada masa depan merupakan harapan yang dipengaruhi oleh ketersediaan karir dipasar tenaga kerja. Chan (2012) menyatakan bahwa pertimbangan pasar kerja meliputi keamanan kerja dan tersedianya lapangan kerja atau kemudahan mengakses lowongan kerja. Hal ini didukung oleh Harris dan Djamhuri (2001) yang berpendapat bahwa sampai saat ini daya serap tenaga kerja yang memiliki kemampuan di bidang akuntansi masih relatif cukup besar mengingat ruang lingkup kerja yang dapat ditangani akuntan cukup luas. Wheeler dalam Law (2010) juga memiliki pendapat yang sama yaitu mahasiswa bisnis, psikologi dan semua pendidikan setuju bahwa penawaran kerja dalam bidang akuntansi lebih baik daripada area bisnis lainnya.

Pertimbangan Pasar Kerja merupakan meliputi keamanan kerja dan tersedianya lapangan kerja atau kemudahan mengaksesnya.

$\mathrm{H}_{5}$ : Pertembangan Pasar Kerja mempunyai pengaruh terhadap pemilihan karir sebagai akuntan

Dari penjelasan variabel-variabel di atas, dapat digambarkan hipotesis penelitian ini seperti digambarkan sebagai berikut.

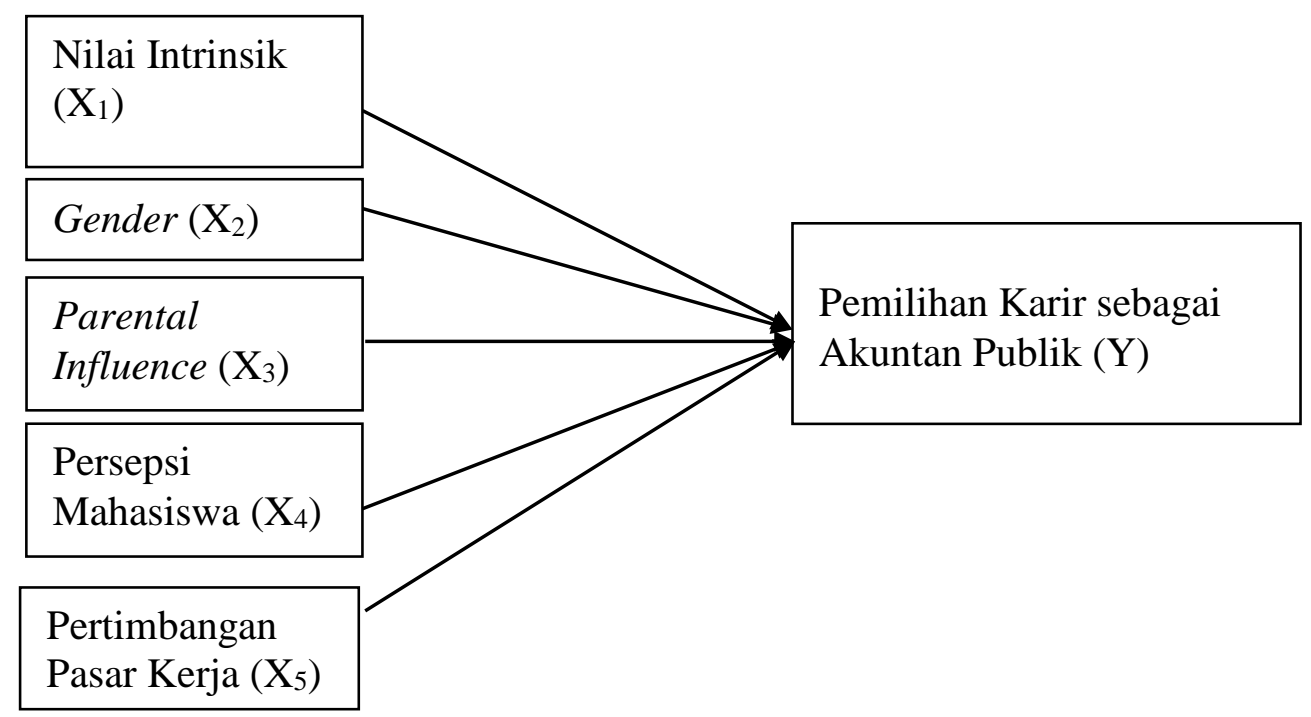

Gambar 2. Rerangka pemikiran

\section{METODE}

Penilitian ini menggunakan metode survei dengan menyebarkan kuesioner atau angket. "Angket merupakan sehimpunan pertanyaan atau pernyataan mengenai suatu objek yang diajukan kepada dan untuk memperoleh tanggapan dari responden" (Aritonang, 1998:153). Data yang digunakan adalam penelitian ini diperoleh dengan mendistribusikan kuesioner ke mahasiswa jurusan akuntansi di tiga perguruan tinggi swasata di Jakarta, 
yaitu Universitas Tarumanagara, Universitas Trisakti dan Universitas Atmajaya. Pemilihan ketiga universitas ini bedasarkan seringnya kantor akuntan besar mengadakan perekrutan tenaga kerja di kampus-kampus tersebut, juga mempertimbangkan besarnya jumlah mahasiswa jurusan akuntansi di tiga perguruan tinggi tersebut. Subyek dibatasi adalah mahasiswa jurusan akuntansi yang telah menyelesaikan mata kuliah pengauditan atau semester akhir. Penyebaran kuesioner langsung ke mahasiswa-mahasiswi dari perguruan tinggi yang bersangkutan dan pengisiannya langsung pada saat kuesioner diberikan. Jumlah kuesioner yang disebarkan ke tiga perguruan tinggi tersebut sebanyak 214 kuesioner dan yang dapat digunakan dalam penelitian ini adalah sebanyak 196 kuesioner.

Operasionalisasi Variabel. (1) Pemilihan Karir sebagai Akuntan Publik. Pengukuran mahasiswa memilih karir sebagai akuntan publik adalah dengan butir pernyataan berupa pertanyaan yang hanya dijawab iya atu tidak untuk menjadi akuntan publik dengan memberikan nilai 0 untuk jawaban tidak dan memberikan nilai 1 untuk yang jawaban ya (Harris dan Djamhuri, 2001). (2) Nilai Intrinsik. Menurut Harris dan Djamhuri (2001) dan Felton, Buhr dan Northey (1994) nilai intrinsik diukur dengan five-point Likert scale melalui butir pernyataan berupa menyukai sebuah pekerjaan yang: memberi tantangan intelektual, memiliki suasana kerja yang dinamis, dan menuntut kreativitas untuk dapat berhasil dan memberikan kebebasan cara penyelesaian tugas. (3) Gender. Menurut Law (2010) gender diukur dengan 0 merepresentasikan wanita dan 1 merepresentasikan pria. (4) Parental Influence. Menurut Tan dan Laswad (2006) parental influence diukur melalui butir pernyataan berupa persanaan responden akan penting refrensi atau pendapat dari orang tua mempengaruhi keputusan pemilihan karir. (5) Persepsi Mahasiswa. Menurut Harris dan Djamhuri (2001) persepsi mahasiswa dapat diukur melalui pernyataan berupa persepsi tentang profesi akuntan publik dan porfesi akuntan lainnya. (6) Pertimbangan Pasar Kerja. Menurut Harris dan Djamhuri (2001) serta Rahayu, Sudaryono dan Setiawan (2003) pertimbangan pasar kerja diukur melalui butir pernyataan penting faktor keamanan kerja lebih terjamin (tidak mudah di PHK) dalam memilih karir bagi Anda. Namun Harris dan Djamhuri (2001) dan Felton, Buhr dan Northey (1994) menambahkan butir lainnya yaitu kesempatan untuk berkembang, pekerjaan yang banyak dibutuhkan, dan pilihan jenis pekerjaan yang fleksibel.

Pengujian data penelitian. Semua data yang sudah masuk melalui tes uji validitas dan realibilitas. Hasil uji dengan tingkat keyakinan 95\%, menghasilkan Uji Validitas untuk semua pertanyaan mempunyai nilai antar 0.192 dan 0.762 (lebih besar dari 0.1178 dan realibilitas antara 0.654 sampai 0.824 (lebih besar 0.60 ).

Selain itu, dilakukan analisis Statistik Deskriptif yang memberikan gambaran tentang jumlah data, ragne, minimum, maksimum, mean, standar deviasi dan variance (Sekaran dan Bougie, 2010:321) untuk menunjukkan ukuran statistik dan dapat digunakan pada pengolahan data selanjutnya. Pengujian berikutnya sebelum melakukan pengujian regresi adalah melakukan pengujian Asumsi Klasik (Uji Multikolinieritas) yang bertujuan untuk menguji apakah model regresi ditemukan adanya korelasi antar variabel bebas (independen)" (Ghozali, 2012:105). Metode pengujian yang digunakan dalam penelitian ini adalah dengan melihat nilai Variance Inflation Factor (VIF) dan tolerance value pada model regresi. Deteksi multikolinieritas pada suatu model regresi dapat dilihat dari nilai 
Variance Inflation Factor (VIF) kurang dari 10 dan tolerance value lebih dari 0,10. Hasil pengujian ini untuk menunjukkan bahwa variabel nilai intrinsik memiliki nilai tolerance $0,727>0,10$ dan nilai VIF 1,375 < 10, gender memiliki nilai tolerance 0,934 > 0,10 dan nilai VIF $1,071<10$, parental influence memiliki nilai tolerance $0,838>0,10$ dan nilai VIF $1,193<10$, persepsi mahasiswa memiliki nilai tolerance $0,663>0,10$ dan nilai VIF $1,508<10$, dan variabel pertimbangan pasar kerja memiliki nilai tolerance 0,894 $>0,10$ dan nilai VIF $1,118<10$. Dengan demikian, dapat disimpulkan bahwa seluruh variabel independen terbebas dari multikolinieritas.

Selain dilakukan pengujian data, juga dilakukan pengujian hipotesis yang terdiri dari pengujian Overall Fit Model yang bertujuan untuk mengetahui apakah suatu model fit dengan data pada saat sebelum dan setelah ditambahkan variabel independen ke dalam model. Model dianggap fit dengan data jika hipotesis nol tidak ditolak yang dilihat dengan adanya penurunan dari nilai -2 Log Likelihood pada Block Number 0 dibandingkan dengan -2 Log Likelihood pada Block Number 1 (Ghozali, 2012:341). Hasil pengujian ini menunjukkan hasil pengolahan data pada Block Number 0 dengan nilai -2 Log Likelihood sebesar 234,522 dan mengalami penurunan pada Block Number 1 dengan nilai -2 Log Likelihood sebesar 185,170. Penurunan -2 Log Likelihood yang terjadi yaitu sebesar 49,352. Dengan demikian dapat disimpulkan bahwa hipotesis nol tidak ditolak yang artinya model regresi logistik yang dihipotesiskan fit dengan data.

Juga dilakukan penilaian terhadap Kelayakan Model Regresi (Goodness of Fitness) yang bertujuan untuk menilai bahwa data empiris cocok atau sesuai dengan model. "Jika nilai statistik Hosmer and Lemeshow Goodness-of-fit lebih besar dari 0,05, maka hipotesis nol tidak dapat ditolak dan berarti model mampu memprediksi nilai observasinya atau dapat dikatakan model dapat diterima"(Ghozali, 2012:341). Hasil dari pengolahan ini menunjukkan nilai chi-square pada Hosmer and Lemeshow's Goodness of Fit Test adalah 13,822 dengan signifikansi 0,087 > 0,05 sehingga dapat disimpulkan bahwa tidak ada perbedaan antara model dengan data (data empiris cocok dengan model) atau model mampu memprediksi nilai observasinya atau dapat dikatakan model dapat diterima karena cocok dengan data observasi.

Uji lain yang dilakukan adalah Uji Koefisien Determinasi $\left(\mathrm{R}^{2}\right)$ dilakukan untuk menunjukkan suatu proporsi dari varian yang dapat diterangkan oleh persamaan regresi terhadap varian total. Untuk model regresi logistik, nilai $\mathrm{R}^{2}$ dilihat dari nilai Cox \& Snell $R$ Square dan Nagelkerke $R$ Square. "Nilai Nagelkerke $R^{2}$ dapat diinterpretasikan seperti nilai $\mathrm{R}^{2}$ pada multiple regression" (Ghozali, 2012:341). "Nagelkerke $R$ Square merupakan modifikasi dari koefisien Cox \& Snell $R$ Square untuk memastikan bahwa nilainya bervariasi dari 0 (nol) sampai 1 (satu)" (Ghozali, 2012:341). Hasil dari pengujian ini adalah Koefisien determinasi pada penelitian ini menunjukkan 0,223 atau 22,3\% untuk nilai Cox \& Snell $R$ Square dan 0,319 atau 31,9\% untuk nilai Nagelkerke $R$ Square. Ini artinya variabilitas variabel dependen yang dapat dijelaskan oleh variabilitas variabel independen adalah sebesar 31,9\%, sisanya 68,1\% dapat dijelaskan oleh variabel lain yang tidak diikutsertakan dalam penelitian ini.

Uji terakhir sebelum melakukan ujia regresi adalah Estimasi Parameter. Model logistic regression digunakan untuk mengetahui ada atau tidaknya terdapat pengaruh nilai intrinsik, gender, parental influence, persepsi mahasiswa dan pertimbangan pasar kerja terhadap pemilihan karir sebagai akuntan publik pada mahasiswa sebagai berikut: 
$\operatorname{Ln}=\alpha+\beta_{1} X_{1}+\beta_{2} X_{2}+\beta_{3} X_{3}++\beta_{4} X_{4}++\beta_{5} X_{5}+e$

di mana: Ln : Odds (probabilitas) pemilihan karir sebagai akuntan Publik (1 memilih karir sebagai akuntan publik, 0 tidak memilih karir sebagai akuntan publik); $\alpha$ : Intersep $\beta_{1}, \beta_{2}, \beta_{3}, \beta_{4}, \beta_{5}, \beta_{6}$ : Koefisien regresi; $X_{1}$ : Nilai intrinsik; $X_{2}:$ Gender; $X_{3}$ :Parental influence; $\mathrm{X}_{4}$ : Persepsi mahasiswa; $\mathrm{X}_{5}$ : Pertimbangan pasar kerja; e :Error (Residual)

Model regresi yang sudah dirumuskan selanjutnya akan diproses dengan menggunakan beberapa pengujian, yaitu: (1) Uji Koefisien Regresi secara Simultan. Uji simultan adalah uji yang dilakukan untuk melihat kemampuan menyeluruh dari variabel independen secara bersama mampu menjelaskan tingkah laku atau keragaman variabel dependen (Suharyadi dan Purwanto, 2009:225). Dari uji secara simultan, menunjukkan semua variabel berpengaruh terhadap variabel dependen; (2) Uji Koefisien Regresi Parsial. Uji parsial digunakan untuk menguji apakah suatu variabel independen secara individual berpengaruh atau tidaknya terhadap variabel dependen. Dasar pengambilan keputusannya adalah dengan melihat nilai signifikan t masing-masing variabel pada output hasil regresi pada significance level $0,05(\alpha=5 \%)$.

Hasil Pengujian Segresi. Hasil hipotesis setelah dilakukan pengujian Uji Koefisien Regresi secara Simultan dan Uji Koefisien secara Parsial dengan tingkat significance level 0,05 (5\% ) disajikan pada Tabel 1.

Tabel 1. Hasil Pengujian Koefisien Regresi secara Parsial

\begin{tabular}{clcccl}
\hline No. & Variabel Independen & $\begin{array}{c}\text { Variabel } \\
\text { Dependen }\end{array}$ & Signifikansi & $\begin{array}{c}\text { Level } \\
\text { Signifikansi }\end{array}$ & Keterangan \\
\hline 1. & Nilai Intrinsik (X1) & Pemilihan & 0,003 & 0,05 & H0 ditolak \\
2. & Gender (X2) & Karir sebagai & 0,009 & 0,05 & H0 diterima \\
3. & Parental Influence (X3) & Akuntan & 0,005 & 0,05 & H0 ditolak \\
4. & Persepsi Mahasiswa(X4) & Publik & 0,267 & 0,05 & H0 ditolak \\
5. & Pertimbangan Pasar Kerja & & & & \\
& (X5) & & & & \\
\hline
\end{tabular}

Sehingga dari hasil uji koefisien regresi tersebut diatas menghasilkan persamaan regresi sebagai berikut:

$$
\begin{aligned}
\operatorname{Ln} & =-8,082+0,269 \mathrm{X}_{1}+\mathrm{X}_{2}+0,149 \mathrm{X}_{3}+0,174 \mathrm{X}_{4}-0,095 \mathrm{X}_{5} \text {, atau } \\
& =\mathrm{e}^{-8,082} \mathrm{Xe}^{0,269 . \mathrm{X} 1} \mathrm{X}^{0,093 . X 2} \mathrm{xe}^{0,149 . X 3} \mathrm{X} \mathrm{e}^{0,174 . X 4} \mathrm{X} \mathrm{e}^{-0,095 . X 5}
\end{aligned}
$$

Hipotesis terhadap masing-masing variable dapat dijelaskan sebagai berikut:

a) Nilai intrinsik $\left(\mathrm{X}_{1}\right)$. Pada tabel 1 menunjukkan bahwa nilai signifikansi untuk variabel nilai intrinsik lebih kecil daripada level signifikansi yaitu 0,003 $<0,05$ sehingga H0 ditolak dengan tingkat signifikan 5\%. Artinya, nilai intrinsik berpengaruh secara signifikan dan positif pada mahasiswa untuk cenderung memilih karir sebagai akuntan publik daripada non akuntan publik. Hal ini sesuai dengan TRA model yang diungkapkan oleh Fishbein dan Ajzen dalam Law (2010) yang mana menurut teori ini tingkah laku seseorang dipengaruhi oleh niat seseorang untuk bertindak dan niat 
tersebut ditentukan oleh attitude serta subjective norms. Nilai intrisik diuji sebagai salah satu komponen yang mencerminkan attitude dalam pemilihan karir sebagai akuntan publik. Sehingga dalam penelitian ini variabel nilai intrinsik dianggap selaras dengan teori tersebut. Penelitian terdahulu yang dilakukan oleh Law (2010), Felton, Burh, dan Northey (1994), dan Jackling and Calero (2006) juga menunjukkan bahwa nilai intrinsik berpengaruh secara signifikan dan positif pada mahasiswa untuk cenderung memilih karir sebagai akuntan publik daripada non akuntan publik seperti pada penelitian ini. Ini artinya terdapat perbedaan pandangan antara mahasiswa yang memilih karir sebagai akuntan publik dan yang non-akuntan publik jika ditinjau dari faktor nilai intrinsik sebuah pekerjaan. Mahasiswa yang memilih karir sebagai akuntan publik rata-rata menyetujui bahwa nilai intrinsik seperti memberi tantangan intelektual, memiliki suasana kerja yang dinamis, menuntut kreativitas untuk dapat berhasil dan memberikan kebebasan cara penyelesaian tugas adalah faktor yang penting dan seharusnya ada untuk diperhatikan dalam sebuah pekerjaan. Sedangkan mahasiswa yang memilih karir sebagai non-akuntan publik rata-rata memiliki pandangan yang netral mengenai faktor nilai intrinsik yang ada pekerjaan yang kelak dipilih.

b) Gender $\left(\mathrm{X}_{2}\right.$ ). Tabel 1 menunjukkan bahwa nilai signifikansi untuk variabel gender lebih besar daripada level signifikansi yaitu 0,827 > 0,05 sehingga $\mathrm{H} 0$ tidak ditolak dengan tingkat signifikan 5\%. Artinya, gender tidak berpengaruh secara signifikan pada mahasiswa untuk cenderung memilih karir sebagai akuntan publik daripada non akuntan publik. Hal ini selaras dengan penelitian yang dilakukan oleh Sugahara, Hiramatsu dan Boland (2009), dan Jackling dan Calero (2006) menunjukkan bahwa gender tidak memiliki pengaruh yang signifikan pada mahasiswa untuk cenderung memilih karir sebagai akuntan publik daripada yang tidak memilih karir sebagai akuntan publik. Artinya, baik pria maupun wanita sama-sama tidak terdapat perbedaan untuk kecendrungan memilih karir sebagai akuntan publik dan non-akuntan publik. Jadi, probabilitas seorang pria untuk cenderung memilih menjadi akuntan publik adalah sama dengan dengan probabilitas seorang wanita untuk cenderung memilih menjadi akuntan publik juga. Begitu juga sebaliknya.

c) Parental influence $\left(\mathrm{X}_{3}\right)$. Tabel 1 menunjukkan bahwa parental influence untuk variabel nilai intrinsik lebih kecil daripada level signifikansi yaitu 0,009 < 0,05 sehingga H0 ditolak dengan tingkat signifikan 5\%. Artinya, parental influence berpengaruh secara signifikan dan positif pada mahasiswa untuk cenderung memilih karir sebagai akuntan publik daripada non akuntan publik. Parental Influence merupakan salah satu komponen TRA model yang diuji dalam penelitian ini yang merupakan interprestasi dari subjective norms yang menjelaskan bahwa tingkah laku seseorang dipengaruhi oleh pendapat atau refrensi dari orang yang dianggap penting (Fishbein dan Ajzen dalam Law, 2010). Pada penelitian ini, orang yang dianggap penting bagi mahasiswa tidak lain adalah orang tua mereka sendiri. Mahasiswa yang memilih karir sebagai akuntan publik rata-rata menyetujui bahwa pandangan orang tua penting dalam memberikan refrensi atau masukan atas karir yang akan dipilih nantinya sedangkan mahasiswa yang memilih karir sebagai non-akuntan publik rata-rata kurang menyetujui bahwa pandangan orang tua penting untuk dijadikan refrensi atas pemilihan karirnya nanti.

d) Persepsi mahasiswa $\left(\mathrm{X}_{4}\right)$. Tabel 1 menunjukkan bahwa nilai signifikansi untuk variabel persepsi mahasiswa lebih kecil daripada level signifikansi yaitu 0,005 $<0,05$ sehingga 
H0 ditolak dengan tingkat signifikan 5\%. Artinya, persepsi mahasiswa berpengaruh secara signifikan dan positif pada mahasiswa untuk cenderung memilih karir sebagai akuntan publik daripada non akuntan publik. Hasil penelitian ini didukung oleh penelitian terdahulu yang dilakukan oleh Gusti et.all (2013), dan Sugahara, Hiramatsu dan Boland (2009) yaitu persepsi mahasiswa tentang profesi akuntan publik memiliki pengaruh yang signifikan dan positif pada mahasiswa yang cenderung memilih karir sebagai akuntan publik daripada non-akuntan publik. Terdapat perbedaan pandangan terhadap citra akuntan publik di mata mahasiswa (persepsi mahasiswa) yang memilih karir sebagai akuntan publik dengan yang memilih karir sebagai non-akuntan publik. Adanya perbedaan inilah yang kemudian menjelaskan bahwa mahasiswa yang setuju jika profesi akuntan publik kelak bisa menjadi konsultan yang dinamis pada perusahaan, menjadi konsultan bisnis yang terpercaya, berpeluang menjadi direktur perusahaan, merupakan pekerjaan yang menarik, penuh tantangan pada awal bekerja, berpenghasilan besar, dan selalu dibutuhkan di perusahaan akan cenderung memilih karir sebagai akuntan publik dibandingkan dengan mahasiswa yang kurang setuju atau netral terhadap pernyataan tersebut.

e) Pertimbangan pasar kerja $\left(\mathrm{X}_{5}\right)$. Tabel 1 menunjukkan bahwa nilai signifikansi untuk variabel pertimbangan pasar kerja lebih kecil daripada level signifikansi yaitu 0,267 > 0,05 sehingga $\mathrm{H0}$ tidak ditolak dengan tingkat signifikan 5\%. Artinya, pertimbangan pasar kerja tidak berpengaruh secara signifikan dan positif pada mahasiswa untuk cenderung memilih karir sebagai akuntan publik daripada non akuntan publik. Hasil penelitian ini selaras dengan penelitian terdahulu yang dilakukan oleh Chan (2012) dan Merdekawati dan Sulistyawati (2011) yang menunjukkan bahwa pertimbangan pasar kerja tidak berpengaruh yang signifikan pada mahasiswa yang cenderung memilih karir sebagai akuntan publik daripada yang tidak memilih karir sebagai akuntan publik. Ini artinya mahasiswa baik yang memilih karir sebagai akuntan publik maupun yang memilih karir tidak sebagai akuntan publik tidak terdapat perbedaan pandangan jika ditinjau dari faktor pertimbangan pasar kerja. Terlihat dari nilai mean pada variabel pertimbangan pasar kerja untuk kelompok yang memilih karir sebagai akuntan publik dengan yang memilih karir tidak sebagai akuntan publik, sama-sama setuju bahwa keamanan kerja yang lebih terjamin, berkesempatan untuk berkembang di bidang lain, pekerjaan yang banyak dibutuhkan dalam dunia bisnis dan dapat bekerja di berbagai jenis industri itu penting dalam pemilihan karir sehingga tidak terdapat perbedaan pandangan antara kedua kelompok (akuntan publik dan non-akuntan publik) tersebut. Jadi mahasiswa sesungguhnya telah mempertimbangkan faktor pasar kerja dalam memilih karir sebagai apapun nantinya.

\section{PENUTUP}

Simpulan. Berdasarkan hasil penelitian di atas, maka dapat dilihat bahwa terdapat perbedaan pandangan pada mahasiswa yang memilih karir sebagai akuntan publik dengan yang non-akuntan publik jika ditinjau dari faktor nilai intrinsik, parental influence, dan persepsi mahasiswa. Mahasiswa yang memilih karir sebagai akuntan publik rata-rata menyetujui bahwa nilai intrinsik yang memberikan tantangan intelektual, suasana kerja yang dinamis, menuntut kreativitas dan memberikan kebebasan cara menyelesaikan tugas penting untuk dijadikan pertimbangan. Pekerjaaan akuntan publik dianggap mengandung 
unsur nilai intrinsik yang diharapkan mahasiswa agar dapat lebih berkembang. Selain itu parental influence juga merupakan faktor yang menentukan mahasiswa yang memilih karir sebagai akuntan publik dengan yang non-akuntan publik yang kemungkinan dorongan orang tua yang kuat setelah para orang tua mengenal profesi akuntan publik. Mahasiswa yang memilih karir sebagai akuntan publik rata-rata menyetujui bahwa pendapat dari orang tua penting dalam memberikan refrensi dan dukungan untuk menjadi akuntan publik nantinya.

Persepsi mahasiswa juga merupakan salah satu faktor yang ikut berpengaruh secara signifikan terhadap pemilihan karir sebagai akuntan publik. Mahasiswa yang memilih karir sebagai akuntan publik rata-rata menyetujui bahwa akuntan publik kelak bisa menjadi konsultan yang dinamis pada perusahaan, menjadi konsultan bisnis yang terpercaya, berpeluang menjadi direktur perusahaan, merupakan pekerjaan yang menarik, penuh tantangan pada awal bekerja, berpenghasilan besar dan selalu dibutuhkan di perusahaan. Sedangkan mahasiswa yang memilih karir sebagai akuntan publik kurang setuju dan netral terhadap pernyataan-pernyataan tersebut.

Keterbatasan dan Implikasi. Penelitian ini jauh dari sempurna dan dilakukan dengan segara keterbatasan dari segi waktu, cakupan subyek dan hanya dilakukan di perguruan tinggi swasta yang lulusannya banyak bekerja di KAP. Dari simpulan yang dijelaskan di atas, perlu dipertimbangkan kantor-kantor akuntan publik menyediakan ruang dan kebebasan bagi auditor untuk menyelesaikan pekerjaan yang ada, memberikan tantangan intelektual dan suasana kerja yang dinamis juga untuk menghindari kebosanan dan meningkatkan keterampilan seperti yang diharapkan mahasiswa.

Peranan orang tua, sebaiknya orang tua juga diberikan informasi yang lebih jelas mengenai karir akuntan publik dan prospek ke depan oleh kantor-kantor akuntan publik. Pertemuaan orang tua dengan lembaga pendidikan dan asosiasi profesi melalui programprogram non-formal bisa dijadikan fasilisator baik untuk kantor akuntan publik , orang tua dan perguruan tinggi agar dapat melakukan komunikasi untuk mendorong dan mendukung putra-putri mereka tertarik menjadi menjadi akuntan publik, sehingga dapat meningkatkan jumlah akuntan publik di Indonesia, dan siap untuk menghadapi Masyarakat Ekonomi Asean diakhir 2015.

\section{DAFTAR RUJUKAN}

Agoes, Sukrisno dan Ardana, I Cenik. (2009) Etika bisnis dan profesi: tantangan membangun manusia seutuhnya. Jakarta: Salemba Empat

Ahmed, Kamran., Alam, Kazi Feroz dan Alam, Manzurul. (1997) An empirical study of factor affecting accounting students' career choice in New Zealand. Accounting Education. 6 (4): 325-335

Allen, Cheryl L. (2004) Business students' perception of the image of accounting. Managerial Auditing Journal. 19 (2): 235-258

Aritonang R, Lerbin R. (1998) Penelitian pemasaran. Jakarta: UPT Universitas Tarumanagara (2005) Kepuasan pelanggan: pengukuran dan penganalisisan dengan SPSS. Jakarta: Gramedia Pustaka Utama 
Auyeung, Pak dan Sands, John. (1997). Factors influencing accounting students' career choice: a cross-cultural validation study. Accounting Education. 6 (1): 13-23

Chan, Andi Setiawan. (2012) Analisis faktor-faktor yang mempengaruhi pemilihan karir menjadi Akuntan publik oleh mahasiswa Jurusan Akuntansi. Jurnal Ilmiah Mahasiswa Akuntansi. 1 (1): 53-58

Felton, Sandra., Buhr, Nola dan Northey, Margot. (1994). Factors influencing the business students' choice of a career in Chartered Accountancy. Issues in Accounting Education. 9 (1): 131-141

Ghozali, Imam. (2012) Aplikasi analisis multivariate dengan program IMB SPSS 20.(6). Semarang: BP Universitas Diponegoro.

Harris, Lutfi dan Djamhuri, Ali. (2001) Analisis tentang faktor-faktor yang melatarbelakangi pemilihan karir bagi mahasiswa Akuntansi: antara Akuntan Publik versus Non Akuntan Publik. TEMA. 2 (2): 116-135

Gusti I Agung, Krisna Lestari dan I Ketut, Yadnyana. (2013) Persepsi dan minat mahasiswa Jurusan Akuntansi Fakultas Ekonomi Universitas Udayana terhadap profesi Akuntan Publik. E-Jurnal Akuntansi Universitas Udayana. 3(1): 195-211

Jackling, Beverley dan Calero, Claude. (2006) Influences on undergraduate students' intentions to become Qualified Accountants: evidence from Australia. Accounting Education: an International Journal. 15 (4): 419-438

Keliat, dkk. (2013) Pemetaan Pekerja Terampil Indonesia dan Liberalisasi Jasa ASEAN: laporan penelitian ASEAN Study Center UI bekerja sama dengan Kementerian Luar Negeri Republik Indonesia. http://www.kemlu.go.id/ Documents/Penelitian\%20BPPK\%202014/Laporan\%20Akhir\%20Liberalisasi\%20Ja sa.pdf

Law, Philip K. (2010) A theory of reasoned action model of accounting students' career choice in public accounting practices in the post-Enron. Journal of Applied Accounting Research. 11 (1): 58-73

Mangunhardjana, A (1997) Isme-isme dalam Etika dari A sampai Z. Yogyakarta: Kanisius.

Maslow, Abraham H. (1987) Motivation and personality. Amerika Serikat: Pearson Education

Merdekawati, Dian Putri dan Sulistyawati, Ardiani Ika. (2011) Faktor-faktor yang mempengaruhi pemilihan karir Akuntan Publik dan Non Akuntan Publik. Aset. 13 (1): 9-19

Mulyadi dan Puradiredja, Kanaka. (1998) Auditing. ed 1. Jakarta: Salemba Empat

Rahayu, Sri., Sudaryono, Eko Arief dan Setiawan, Doddy. (2003) Persepsi mahasiswa Akuntansi mengenai faktor-faktor yang mempengaruhi pemilihan karir. Simposium Nasional Akuntansi VI. hal. 821-838

Robbins, Stephen P dan Coulter, Mary. (2008) Management. ed 10. Jakarta: PT Index Gramedia

Sekaran, Uma dan Bougie, Roger. (2010) Research methods for business. 5th ed. Sussex UK: Wiley

Sugahara, Satoshi., Hiramatsu, Kazuo dan Boland, Greg. (2009) The factors influencing accounting school students' career intention to become a Certified Public Accountant in Japan. Asian Review of Accounting. 17 (1): 5-22 
Suharyadi dan Purwanto. (2009) Statistika untuk ekonomi dan keuangan modern. ed 2. Jakarta: Salemba Empat

Tan, Mei Lin dan Laswad, Fawzi. (2006) Students' beliefs, attitudes and intention to major in Accounting. Accounting Education: an International Journal. 15 (2): 167187

Undang-Undang Republik Indonesia Nomor 5 Tahun 2011 Tentang Akuntan Publik 